\title{
Analisis Model Problem Based Learning dalam Pembelajaran Abad 21 dari Segi Karakteristik Peserta Didik
}

\author{
Nopi Arissandi \\ SDIT BIAS Assalam Tegal \\ nparissandi69@gmail.com
}

\section{Article History}

received 3/12/2020

\begin{abstract}
The development of the times is getting faster, changing attitudes and patterns of human thinking. Likewise, the characteristics of students also experience changes. The role of education is very important in preparing students to have 21st century skills. One of the efforts to face the challenges of 21st century learning is to change the teacher's role from providing and delivering information to being a facilitator to share information and practice problem solving skills to students. Constructivism approach is one of the alternatives in 21st century learning. Problem Based Learning learning model is one of the most popular models in constructivism approach. However, there are still many educators who experience confusion in implementing these learning steps. And answer whether the model is in accordance with the character of 21st century students.
\end{abstract}

Keywords: Problem Based Learning, learning, characteristics, elementary school

\begin{abstract}
Abstrak
Perkembangan zaman yang semakin cepat, mengubah sikap dan pola berpikir manusia. Begitu pula karakteristik peserta didik juga mengalami perubahan. Peran Pendidikan menjadi sangat penting dalam mempersiapkan peserta didik agar memiliki keterampilan abad 21. Salah satu upaya untuk menghadapi tantangan pembelajaran abad 21 dengan merubah peran guru dari penyedia dan penyampaian informasi menjadi fasilator untuk berbagi informasi dan melatih kemampuan memecahkan masalah kepada peserta didik. Pendekatan konstruktivisme menjadi salah satu alternatif dalam pembelajaran abad 21. Model pembelajaran Problem Based Learning merupakan salh satu model yang paling popular pada pendekatan konstruktivisme. Namun, masih banyak para pendidik yang mengalami kebingungan dalam menerapkan langkah-langkah pembelajaran ini. Serta menjawab apakah model tersebut sesuai dengan karakter peserta didik abad 21.
\end{abstract}

Kata kunci: Problem Based Learning, pembelajaran, karakteristik, sekolah dasar

Social, Humanities, and Education Studies (SHEs): Conference Series https://jurnal.uns.ac.id/shes

p-ISSN 2620-9284

e-ISSN 2620-9292 


\section{PENDAHULUAN}

Di era globalisasi, perkembangan zaman dan teknologi sangat cepat. Dengan seamakin cepatnya perkembangan teknologi, mengubah sikap serta pola pikir manusia. Terjadi pergeseran paradigma Pendidikan. Berbagai tantangan-tantangan mulai melanda dalam dunia Pendidikan tertama pada pembelajaran. Missal semula guru sebagai pusat dalam pembelajaran sekarang bergeser menjadi pembelajaran yang berpusat atau beorientasi pada peserta didik.

Pendidikan merupakan aspek penting dalam menghadapi perkembangan zaman yang penuh dengan tantangan dan perubahan. Melalui Pendidikan diharapkan membentuk peserta didik sebagai generasi penerus bangsa yang memiliki karakter yang kreatif, inovatif, komunikatif, dan terampil. Dalam proses pembelajaran untuk mengembangkan kreativitas peserta didik, kemampuan berpikir kritis peserta didik merupakan salah satu hal yang sangat penting karena dengan berpikir kritis peserta didik dapat menggunakan potensi akal secara maksimal untuk memecahkan suatu permasalahan yang dihadapinya dalam kehidupan sehari-hari (Rahmadani, 2019).

\section{A. Model Problem Based Learning}

\section{HASIL DAN PEMBAHASAN}

Menurut Trianto (2010), model pembelajaran Problem Based Learning (PBL) merupakan suatu model pembelajaran yang didasarkan pada banyaknya permasalahan yang membutuhkan penyelidikan autentik yakni penyelesaian nyata dari permasalahan nyata. Model Problem Based Learning disebut juga pembelajaran berbasis masalah. Pembelajaran berbasis masalah meliputi pengajuan pertanyaan atau masalah pada dunia nyata, memusatkan pada keterkaitan antar disiplin, penyelidikan asli/autentik, kerjasama dan menghasilkan karya serta peragaan. Menurut Arends (2008) langkah-langkah (sintak) model pembelajaran Problem Based Learning sebagai berikut.

\section{Orientasi peserta didik kepada masalah}

Pada orientasi masalah, guru menjelaskan apa tujuan pembelajaran, bagaimana proses pembelajaran yang akan dilaksanakan, dan memotivasi peserta didik terlibat dalam aktivitas pemecahan masalah yang dapat dipilih. Guru dapat menyampaikan orientasi masalah dengan cara memotivasi siswa untuk antusias dan siap belajar. Misalnya dengan meminta siswa menebaknebak kemungkinan yang akan terjadi atas masalah yang diberikan guru. Guru juga dapat menghubungkan tujuan pembelajaran yang akan dicapai dengan tujuan pembelajaran yang lalu.

\section{Mengorganisasikan peserta didik}

Guru membantu peserta didik dalam mendefinisikan dan mengorganisasikan tugas belajar yang berhubungan dengan masalah tersebut. Pendefinisian masalah harus memenuhi kriteria autentik, jelas, mudah dipahami, luas sesuai tujuan pembelajaran, dan bermanfaat.

\section{Membimbing penyelidikan individu dan kelompok}

Guru membantu peserta didik untuk mengumpulkan informasi yang sesuai, melakukan eksperimen untuk mendapatkan penjelasan dan pemecahan masalah, pengumpulan data, hipotesis, dan pemecahan masalah. Guru berperan sebagai fasilitator pada peserta didik untuk menemukan penyelesaian dengan cara yang teknologis, berpikir kritis, dan melatihn kreativitas.

\section{Mengembangkan dan menyajikan hasil karya}

Guru membantu peserta didik dalam merencanakan dan menyiapkan karya yang sesuai seperti laporan, eksperimen dan demonstrasi. Hasil karya tersebut dapat dipresentasikan yang dapat dilihat oleh setiap peserta didik yang ada. 


\section{Menganalisis dan mengevaluasi proses pemecahan masalah}

Guru membantu peserta didik untuk melakukan refleksi atau evaluasi terhadap penyelidikan mereka dan proses-proses yang digunakan.

\section{B. Pembelajaran Abad 21}

Menurut Pujiriyanto (2019), Bishop mengemukakan orientasi-orientasi pembelajaran abad 21 dalam bentuk berbagai keterampilan abad 21 yang penting dikuasai peserta didik untuk menjadi warga negara dan insan yang kreatif produktif di abad 21 . Keterampilan abad 21 menjadi orientasi pembelajaran di Indonesia, antara lain sebagai berikut:

1. Berpikir kritis dan penyelesaian masalah (critical thinking and problem solving).

Berpikir kritis merupakan keterampilan yang diperlukan peserta didik untuk menghadapi kompleksitas dan ambiguitas informasi yang besar. Pesertadidik perlu dibiasakan untuk berpikir analitis, membandingkan berbagai kondisi,dan menarik kesimpulan untuk dapat menyelesaikan masalah.

2. Kreatifitas dan inovasi (creativity and innovation).

Kreatifitas dan inovasi merupakan kunci pertumbuhan bagi negara berkembang. Kurikulum 2013 memiliki tujuan mempersiapkan manusia Indonesia agar memiliki kemampuan hidup sebagai pribadi yang beriman, produktif, kreatif, inovatif dan afektif.

3. Pemahaman lintas budaya (cross-cultural understanding).

Keragaman budaya di Indonesia sangat penting dipahami oleh peserta didik selain pengenalan keragaman budaya lintas negara. Peserta didik harus memiliki sikap toleransi dan mengakui eksistensi dan keunikan dari setiap sukudan daerah yang ada di Indonesia.

4. Komunikasi, literasi informasi dan media (media literacy, information, and communication skill).

Keterampilan komunikasi dimaksudkan agar peserta didik dapat menjalin hubungan dan menyampaikan gagasan dengan baik secara lisan, tulisan maupun non verbal. Literasi informasi dimaksudkan agar peserta didik dapat mempergunakan informasi secara efektif yakni memahami kapan informasi diperlukan, bagaimana cara mengidentifikasi, bagaimana cara menentukan kredibilitas dan kualitas informasi. Literasi media dimaksudkan agar peserta didik mampu memahami, menganalisis, dan adanya dekonstruksi pencitraan media, ada kesadaran cara media dibuat dan diakses sehingga tidak menelan mentah-mentah berita dari media.

5. Komputer dan literasi Teknologi Informasi dan Komunikasi (computing and ICT literacy)

Literasi TIK mengandung kemampuan untuk memformulasikan pengetahuan, mengekpresikan diri secara kreatif dan tepat, serta menciptakan dan menghasilkan informasi bukan sekedar memahami informasi.

6. Karir dan kehidupan (life and career skill)

Peserta didik akan berkarya dan berkarir di masyarakat dimana dunia kerja memerlukan orang-orang yang mandiri, suka mengambil inisiatif, pandai mengelola waktu, dan berjiwa kepemimpinan

Keenam keterampilan di atas dapat dikelompokkan menjadi tiga kategori, yaitu; (1) keterampilan belajar dan inovasi meliputi berpikir kritis dan pemecahan masalah, komunikasi dan kolaborasi, serta kreatifitas dan inovasi, (2) literasi digital meliputi 
literasi informasi, literasi media, dan literasi TIK, dan (3) keterampilan dalam karir dan kehidupan

\section{Karakteristik Peserta Didik Abad 21}

Peserta didik di abad 21 merupakan bagian dari generasi $z$ atau generasi milenial yang manaa generasi ini terbiasa dengan teknologi sejak lahir (Pujiriyanto, 2019). Karakteristik peserta didik abad 21 antara lain:

1. Menyukai kebebasan dalam belajar (self directed learning)

2. Suka mempelajari hal-hal baru

Dengan melihat kenyataan bahwa anak-anak senang dengan segala aktivitas maka kita sebagai guru hendaknya memberikan kegiatan pada anak untuk menunjang intelegensinya. Untuk itu, anak dilatih untuk berpikir atau mencoba memecahkan suatu masalah.

3. Merasa nyaman dengan lingkungan yang terhubung dengan jaringan internet. Saat ini, anak-anak cenderung menghabiskan banyak waktunya untuk menggunakan computer, video game, digital music player, video cams, handphone, dan seluruh perangkat digital lainnya (Sapa'at, 2019)

4. lebih suka berkomunikasi dengan gambar images, ikon, dan simbol-simbol daripada teks.

Menurut Sapa'at (2012) anak-anak adalah "native speaker" yang hidup bersahabat dengan komputer, video games, dan internet. Mereka lebih menyukai berbagai gambar, suara, dan video dibandikan dengan teks sebagai sumber bacaan.

5. Memiliki rentang perhatian pendek (short attention span) atau dengan kata lain sulit untuk berkonsentrasi dalam jangka waktu lama.

6. Berinteraksi secara kompleks dengan media seperti smartphone, televisi, laptop, desktop, dan iPod.

Anak-anak lebih menyukai cara-cara yang singkat dalam waktu yang bersamaan. Tidak heran jika kita melihat anak-anak kita sering mendengarkan musik, mengetik sesuatu di computer, dan mencari informasi di computer secara bersamaan.

7. lebih suka membangun eksistensi di media sosial daripada di lingkungan nyata.

\section{SIMPULAN}

Salah satu keberhasilan proses pembelajaran adalah peserta didik merasa senang dimana guru mampu untuk memfasilitasi pembelajaran yang sesuai dengan karakteristik peserta didik. Dalam Problem based Learning, pemahaman, transfer pengetahuan, keterampilan berpikir kritis, kemampuan memecahkan masalah dan kemampuan komunikasi ini merupakan dampak langsung dari pembelajaran.

Dampak penyerta dari Problem based Learning meliputi peluang peserta didik memperoleh pengetahuan, meningkatkan keterampilan memecahkan masalah, meningkatkan kemampuan untuk memperoleh pengetahuan yangrelevan, membangun pengetahuannya sendiri, menumbuhkan motivasi dalam belajar,meningkatkan keterampilan peserta didik dalam berpikir, meningkatkan komunikasi dan bekerja sama dalam kelompoknya. Semua dampak penyerta ini diharapkan menjadi sikap peserta didik ketika menemukan masalah di dalam konteks kehidupan sehari-hari. Pembelajaran ialah membelajarkan siswa menggunakan asas pendidikan maupun teori belajar merupakan penentu utama keberhasilan pendidikan. Pembelajaran merupakan proses komunikasi, komunikasi yang dilakukan antara guru ke siswa atau sebaliknya, dan siswa ke siswa. 
DAFTAR PUSTAKA

Arends, R. (2008). Learning to Teach. Jakarta: Pustaka Belajar.

Miyarso, Estu. (2019). Perancangan Pembelajaran Inovatif. Jakarta: Kementrian Pendidikan dan Kebudayaan.

Muhtadi Ali. (2019). Pembelajaran Inovatif. Jakarta: Kementrian Pendidikan dan Kebudayaan.

Munawaroh, Isniatun. (2019). Modul Konsep Dasar Ilmu Pendidikan. Jakarta: Kementrian Pendidikan dan Kebudayaan.

Pujiriyanto. (2019). Peran Guru Dalam Pembelajaran Abad 21. Jakarta: Kementrian Pendidikan dan Kebudayaan.

Rahmadani. 2019. Metode Penerapan Model Pembelajaran Problem Based Learning ( PBL). Lantanida Journal, Vol.7 No. 1 (2019) 1-100

Sanjaya, Wina. (2007). Strategi Pembelajaran Berorientasi Standar Proses Pendidikan. Jakarta: Kencana.

Sapa'at, Asep. (2012). Stop Menjadi Guru. Jakarta: Tangga Pustaka.

Trianto. (2009). Mendesain Model Pembelajaran Inovatif-Progresif . Jakarta: Kencana Prenada Media Grup

Trianto. (2010). Model Pembelajaran Inovatif Berorientasi Konstruktivitik . Jakarta: Prestasi Pustaka.

Tyas, Retnaning. (2017). Kesulitan Penerapan Problem Based Learning dalam PembelajaranMatematika. Tecnoscienza Vol.2 No.1 Oktoer 2017

Wardani, IGAK. (2018). Materi Pokok Perseptif Prndidikan SD. Tangerang Selatan: Universitas Terbuka 